\title{
EGFR NM_005228.3:c.2302_2303ins9
}

National Cancer Institute

\section{Source}

National Cancer Institute. EGFR NM 005228.3:C.2302 2303ins9. NCI Thesaurus. Code C98610.

An insertion of nine nucleotides, CGCT GGCCA, between position 2302 and 2303 of the coding sequence of the EGFR gene. 